\title{
THE VALUE OF APOLOGIES IN LAW AND MORALITY
}

\author{
ALBERTO PINO-EMHART ${ }^{1}$
}

\begin{abstract}
The paper explores the role of apologies in cases of wrongdoing, in the context of both morality and the law, particularly the law of torts. It is shown that apologies are morally required in a strong sense, seeking to repair or reestablish moral relationships from the perspective of restorative justice. Moreover, it is argued that this restorative function is also relevant for the practice of tort law, in which the process could also aim at re-establishing the normative relationship between the parties, and communicating a restorative message to the victim, like apologies. It is discussed whether compensatory remedies in tort law could perform this restorative function, opening the space for further work over this symbolic function that tort systems could potentially perform.
\end{abstract}

KEYWORDS: Apologies; Restorative Justice; Moral Reconciliation; Tort Law.

\section{ApOlogies IN OUR MORAl LiVES}

Using the term 'losses' in the broadest sense possible, it could be said that people suffer losses all the time in their daily lives. Some of these losses have severe consequences for people, such as the damages caused by natural disasters, whereas other losses do not have serious consequences, such as when someone arrives late to a meeting with a friend. Yet only a few of these losses are compensated. Some of them are due to human interaction, but others are not. Some of these are material losses that can easily be compensated (i.e. the restitution of a book that a friend has lost), whereas other losses are nonmaterial and more difficult - or even impossible - to compensate. In some cases, it seems that a simple apology is enough as a response to a loss; in other situations, we would say that compensation or restitution is enough; and finally in other cases it seems that both apologies and compensation are required. Consider the following situation based on a simple daily interaction:

(i) Alfred is at the groceries fair market waiting on the line to pay. Suddenly, Barbara skips the line and puts herself ahead of Alfred. Alfred is very upset and loses time because of Barbara's action.

\footnotetext{
${ }^{1}$ Assistant Professor, Universidad Adolfo Ibáñez, Chile.
} 
In this scenario, a basic moral intuition is that Barbara did something wrong to Alfred, and therefore that a remedy from Bernard is required. But what sort of remedy would be appropriate in a case like this? Is it enough if Barbara apologises, or something else is required? It seems that a sincere apology from her would be enough to repair the wrong committed. Probably, if Alfred were still angry with Barbara after a sincere apology was offered, we would think that he is overreacting. But is it appropriate for Barbara to compensate Alfred for what she did to him? We can imagine, for instance, Barbara saying 'I am so sorry, would you allow me to pay for your groceries in compensation?'. Her action here would be risky; though her honest intention of seeking to repair the injury she has caused is praiseworthy, it might be deemed as inappropriate by Alfred. There is a worry therefore regarding the action of compensation as a response to a wrong, namely: in some cases, compensation might be deemed inappropriate to repair injuries by their victims. In some contexts, compensation can even cause a new injury. In our situation, Barbara's offer might be offensive to Alfred, because he could perceive that she is trying to buy him off. Clearly, this is not a conflict about material redress, and therefore it is perfectly normal in this context to react against an offer of economic redress. It seems to me that the key point here is that if Barbara offers economic redress she might be communicating the wrong message. Anyone could interpret her as saying 'I am wealthy, I can do whatever I want as long as I provide compensation to my potential victims'. Barbara's compensation act would therefore be creating a new injury to Alfred, regardless of Barbara's genuine intention to make amends.

It is possible however to conceive a scenario in which Barbara's offer of compensation could be an adequate mechanism of reparation. Suppose that Barbara, by getting in the line before Alfred, was able to get the last box of strawberries left at the market, and that Alfred wanted to buy strawberries. After realising what she did, Barbara apologises to Alfred, and she also gives the box of strawberries to him. It might be questioned whether this is really a form of compensation or not, especially if Alfred agrees to pay Barbara the price that she paid for the strawberries. But in such a case, it is clear that a simple apology would not be enough, because Alfred lost his opportunity to buy the strawberries (which, we can assume, are the best in town). Perhaps Barbara is only giving back to Alfred this opportunity to buy the strawberries, an opportunity that she had only because she committed a wrong against him. Imagine now that Alfred and Barbara are friends. Barbara feels the need to apologise to Alfred, but she also wants to provide some form of compensation to him. After the incident then, she sends a box of chocolates to Alfred by post. In this case, Barbara's compensation does not seem inappropriate. The fact that they know each other changes the meaning of the compensatory gesture; it does not communicate superiority or indifference regarding Alfred's feelings. On the contrary, Barbara's gift shows that she really cares about her friend's feelings, and that she regrets what she did. 
This short discussion shows that the context is important to determine whether an apology or some form of compensation is required in a given case (or some combination of both). In some contexts, compensation offers might be out of place when they communicate a message of superiority or indifference regarding the victim's feelings. In these cases, a victim might feel that the injurer is getting away too easily; paradoxically, in such cases it might look that compensation is being used to avoid rather than to assume responsibility for the injury. Other contexts however allow injurers to offer compensatory measures without being disrespectful to their victims, such as in our case when there is a previous connection of friendship between Alfred and Barbara.

In situation ( $i$ ) it is clear that Barbara should apologise to Alfred, regardless of whether compensation is also required or not. Let us consider now situation (i) with a slight modification:

(ii) Alfred is at the groceries fair market waiting on the line to pay, but he gets distracted for a few seconds choosing some plums that he adds to his basket. While Alfred is looking at the plums, Barbara wants to join the line to pay, and without realising that Alfred is on the line, she puts herself before him. Alfred is very upset and loses time because of Barbara's action.

The situation has changed now, because Barbara did not have the intention to skip the line; she only did it accidentally. Is there a duty to apologise here? It could be argued that Barbara was negligent by not asking Alfred whether he was on the line or not. She should regret what she did, and she should therefore apologise. But is this apology similar to the apology required in situation (i)? In philosophical terms, apologies have been classified as illocutionary expressive speech acts. ${ }^{2}$ As illocutionary acts, apologies characteristically have a meaning beyond the mere utterance of the sounds or marks used on their performance (e.g. 'I am sorry', 'I apologise'). ${ }^{3}$ It follows that apologies are essentially symbolic: they express or communicate a message.

It is important therefore to analyse which messages are being expressed in both apologies. In the first situation, Barbara could say 'I am sorry, I took a wrong decision', whereas in situation (ii) we could expect Barbara to say 'I am sorry, but I did not realise you were on the line'. The utterance of the sound 'sorry' in both apologies could be misleading, but they express different messages. In the apology of situation (i), Barbara is expressing regret for what she did, and is also acknowledging that she was wrong. It could be argued that this is the case of a

\footnotetext{
2 John Searle, Speech Acts: An Essay in the Philosophy of Language (Cambridge University Press 1969) 23.

3 ibid 42.
} 
perfect apology, or as Nick Smith would put it, a 'categorical apology'. ${ }^{4}$ Barbara's apology in situation (ii), on the other hand, has a different meaning. For Smith this apology would not be perfect or categorical, because when Barbara claims that she did not realise that Alfred was on the line, she is refusing to accept blame. ${ }^{5}$ According to Smith, whenever injurers use the formulation 'I am sorry but...' and make an excuse for what they did, they reveal an uncertainty regarding whether they commit a wrong or not. ${ }^{6}$

It is important to note that Smith does not claim that an apology without an acceptance of blame is not an apology; he only argues that such apologies do not have the same meaning that categorical apologies have. ${ }^{7}$ I share Smith's view that we should care more about the meaning that different types of apologies have, rather than to determine which are the necessary conditions of apologies. ${ }^{8}$ However, it seems to me that a robust account of apologies should include situations like (ii), in which there is some degree of uncertainty regarding who caused the injury. Smith requires that injurers 'parse precisely for what [they are] causally responsible', an operation that 'opens a range of notoriously knotty issues regarding the metaphysics of causation and its relation to moral responsibility'.$^{9}$ If determining causation in a given case is a tricky operation, as Smith acknowledges, why then should we demand from injurers to establish precisely for what are they causally responsible? In many situations, we feel responsible for what happened, but we do not think that we should be entirely blamed for it. Consider the following situation:

(iii) David is driving his car while he is tuning a radio looking for a good song. Distracted with the radio, he suddenly realises that Caroline is illegally crossing the street right in front of his car. Caroline sees David's car too late, whereas David tries to do an

\footnotetext{
${ }^{4}$ According to Smith, a categorical apology is the 'regulative ideal' for apologies. He claims that they 'are demanding ethical acts indicating a kind of transformation that resonates with thick conceptions of repentance within religious traditions. Nick Smith, I Was Wrong: The Meaning of Apologies (Cambridge University Press 2008) 142.

${ }^{5}$ Compare with John Gardner's recent formulation of a 'model apology', conceived as an expression of 'the apologizer's heartfelt wish that things had been otherwise with what she did, although it does not necessarily wish that, all in all, she had done otherwise'. John Gardner, From Personal Life to Private Law (Oxford University Press 2018) 145 (emphasis added).

${ }^{6}$ 'If a legitimate excuse follows the "but", then an apology accepting blame may not be warranted'. ibid 49.

7 'Not all injuries call for categorical apologies, and we can seek more or less apologetic meaning depending on the circumstances. ibid 143.

8 The latter approach can be found in Kathleen Gill, 'The Moral Functions of an Apology' (2000) 31 The Philosophical Forum 11, 14 and Louis F. Kort, 'What is an Apology?' in Rodney C. Roberts (ed), Injustice and Rectification (Peter Lang 2002) 110.

${ }_{9}^{9}$ Smith (n 4) 38.
} 
emergency stop, but unfortunately he runs over Caroline. She suffers severe physical injuries and is very upset with David, because she knows that he would have been able to stop on time were he not distracted with the radio.

It is clear that an apology is required here. But what sort of apology could we demand from David? A categorical apology would require him to establish accurately that he should be blamed entirely for the accident. In this case, David would be blamed because he was negligent in his driving, a negligence that caused (at least in terms of but-for causation) Caroline's injuries. Accidents however are often not caused unilaterally by only one of the parties involved. Particularly in this case, Caroline was also negligent, because she should not have crossed in the middle of the street. Again, in terms of a but-for test of causation, it is clear that her negligence also caused the accident. Lawyers would usually explain this in terms of contributory negligence: David should be liable to redress Caroline's injuries, but he should also be entitled to a reduction of the damages to be paid considering Caroline's recklessness. Why should we not apply the same rule to apologies? Indeed, we could expect David to say 'I am sorry, I got distracted with the radio (acknowledging his negligence), but you appeared out of nowhere in the middle of the street (remarking Caroline's contributory negligence)'. As we have seen, according to Smith such an apology would not be categorical, since he is only partially accepting blame for the accident. But it seems to me that the problem here is not with the apology. In this particular context, David would be satisfying the demands of reparation provided that he apologises to Caroline with an expression such as the aforementioned, and that he compensates the injuries adequately (according to the percentage of his negligence's contribution to the damages).

The problem is that apologies in accidents like situation (iii) frequently demand injurers to accept blame only partially, as far as they are causally responsible for the damages. Smith acknowledges that in some cases there is uncertainty regarding causation, and that fact explains why we often respond with counter-apologies when someone apologises to us (such as 'do not worry for being late, I was a bit late too'). For Smith, with counter-apologies victims share the burden of the blame with the injurers, and they 'serve as recognitions of the difficulties of assigning moral responsibility and isolating fault'. ${ }^{10}$ However, it seems to me that in situation (iii) assigning moral responsibility should not be difficult; it is rather straightforward that both David and Caroline should share the burden of the blame for the accident. David does not need to be a lawyer - nor to have any knowledge of the law whatsoever - to understand that he does not need to accept all the blame for this accident. A sophisticated account of proximate causation is not required here to understand that both negligent acts are causally relevant to the event.

10 ibid 45 . 
Perhaps Smith is not interested in the study of apologies in accidents. In a previous article, he argued that ' [a]pologies for accidents (...) seem to have no more meaning than expressions of sympathy'. ${ }^{11}$ If apologies for accidents are left out of the analysis, why then should we care so much about categorical apologies? It is true that it is important to understand apologies in the context of intentional wrongdoing, but I cannot see a reason why should we not be also interested in apologies in the context of unintentional injuries, especially when negligence is involved. In fact, it is more frequent in our moral lives to apologise for unintentional harms than intentional ones. Smith mentions that the study of 'when and how to apologize' is useful to gain a better understanding of daily interactions. He even illustrates this idea with the example of his failure to take the trash out of the house as his spouse requested. According to Smith, with the analysis of apologies it is possible to 'identify the deeper underlying harm (such as not listening to or respecting her)' involved here. ${ }^{12}$ But there is another possibility: he could only have forgotten to take the trash out. In such case, Smith would need to apologise to her spouse not because he had disrespected her, but rather for being negligent. Why should he not be able to apologise to his spouse, saying that he did not have the intention to cause any harm? ${ }^{13}$

My point is that an apology that accepts blame in terms of negligence should not be less worthy than Smith's categorical apology, even if a negligent apologiser -such as David in situation (iii) - does not acknowledge that he is entirely responsible for the accident. Smith seems to agree with this view, when he claims that 'I can consistently accept blame and apologize for committing a wrong even if I believe that the victim shares some responsibility with me or that I bear no culpability for some portion of the harm'. ${ }^{14}$ It is not clear however what does it mean to say that the injurer can 'consistently accept blame and apologize for committing a wrong'. Does it include David's apology in the form 'I am sorry, but...'? It cannot be, because as was seen above, Smith claims that categorical apologies cannot include legitimate excuses. Another possibility is to argue that David should apologise accepting all the blame, even if he believes that the burden of the blame should be shared with Caroline. ${ }^{15}$

\footnotetext{
${ }^{11}$ Nick Smith, 'The Categorical Apology' (2005) 36 Journal of Social Philosophy 473, 479.

${ }^{12}$ Smith (n 4) 12.

${ }^{13}$ In a similar way, Gardner argues that in some contexts, a mere formal apology could 'be more worth giving and more worth having, indeed, than a model apology'. Gardner (n 5) 146.

14 ibid 46.

${ }^{15}$ Perhaps this would have fitted the 'traditional attitude' of English common law, in which the courts were reluctant to apply rules of contributory negligence. See Tony Weir, 'ALL or Nothing?' (2004) 78 Tulane Law Review 511. In my view, the fact that this attitude now has changed reflects the unfairness of requiring people to apologise for events that they are not causally responsible for. By contrast, a recent defence of the traditional attitude can be found in Robert Stevens, 'Should Contributory Fault be Analogue or Digital?' in Andrew Dyson and others (eds.), Defences in Tort (Hart Publishing 2015).
} 
Perhaps David could accept all the blame expecting a counter-apology from Caroline, just like people sometimes make offers without expecting that they will be accepted. That might be the case, but this solution does not save the main objection to categorical apologies: why should David have the obligation to apologise accepting all the blame? As a courtesy, he could do that. But as a courtesy he could do many other things. For instance, he could visit her at the hospital during the following days, or he could buy her a car. But we would never say that David is morally required to do any of these things, whereas he is morally required to apologise for his negligent driving that caused (at least partially) Caroline's injuries. How can we solve this problem for apologies? Should we conclude then that apologising for negligent behaviour is only part of a scheme of (morally soft) courtesy or etiquette rules?

I argue that apologies are morally required in a stronger sense than mere etiquette rules. When injurers do not apologise moral relationships can be seriously harmed, even strong relationships such as marriage. As was noted above, apologies in accidents are problematic for Smith because they are often caused by more than one party's fault. If a given harm was unintentional, argues Smith, then the apology 'gives the victim no reason to believe that it will not happen again'. ${ }^{16}$ Of course, if one uses as a perfect model the apology for intentional wrongdoing, apologies for accidents will be problematic. But it makes sense that we apologise for being negligent, despite the fact that we cannot completely guarantee that it will not happen again. Human beings are fragile and make mistakes all the time. This does not mean however that someone like David could not sincerely commit to drive more carefully from now on. There will always be doubts on whether he will be able to meet this commitment or not; but the same doubts could be posted on whether an injurer who caused an intentional harm will do it again or not. ${ }^{17}$

Counter-apologies reflect this fragility of human beings. It is true, as Smith argues, that in some cases counter-apologies share the burden of blame due to the problematic aspects of causation. But as we have seen, in many cases causation is relatively clear. It seems to me that in those cases counter-apologies are used with a different purpose, which is to acknowledge a reciprocity feature on our daily interactions. ${ }^{18}$ If a friend arrives late to a lunch meeting with me because he was negligent, after apologising to me I might counter-apologise to him as well. The reason I might do this is not because causation is uncertain, but rather because next time the same could happen to me. We are all potentially subject to be involved in

\footnotetext{
${ }^{16}$ Smith (n 11) 479.

${ }^{17}$ In fact, according to Smith it is not possible to judge the quality of an apology at the moment it is given: 'we can only judge [the] ultimate quality of the apology over the duration of the offender's life'. ibid 483-4.

${ }^{18}$ This reciprocity feature of our moral practices satisfies what Honoré identifies as a requirement of fairness for an outcome allocation system of liability. Tony Honoré, 'Responsibility and Luck. The Moral Basis of Strict Liability' in his Responsibility and Fault (Hart Publishing 1999) 26.
} 
accidents caused by our negligence. It is not possible for my friend to reassure me that he will not be late ever again (though he might say that). There is no way to know whether my friend will be able to arrive on time to all of our next meetings. Maybe he will. But he is fragile as a human being, and even if he endeavours to arrive on time, he might still be late.

In sum, apologies in the context of unintentional harms make moral sense when they can be morally attributed or allocated to the person who caused (at least partially) the injury. It is possible to claim that these apologies are imperfect (or not categorical), because injurers cannot guarantee that they will not be negligent again. But as was noted above, apologies for intentional wrongdoing cannot either provide such a guarantee. Additionally, and regardless of the lack of this guarantee, apologies for accidents are often accepted more easily, or they are in some cases received with counter-apologies. The reason for this is that in the context of accidents, there is a reciprocity feature on the interactions among human beings that raise these duties to apologise: a victim who is receiving an apology for an injury today, might be apologising tomorrow for committing the same injury. But I have not shown yet that these duties to apologise are morally stronger than mere etiquette rules. I shall argue this point by exploring throughout the next sections the connection between the duty to apologise and the duty to compensate, which is usually identified as a moral duty in a strong sense. ${ }^{19}$

\section{APOLOGIES AND COMPENSATION: A HAPPY OR UNHAPPY MARRIAGE?}

To illustrate the connection between apologies and compensation, let us consider now situation (iv), which introduces a few changes to situation (iii):

(iv) Elizabeth is driving her car while she is tuning a radio looking for a good song. Distracted with the radio, she suddenly realises that Frank's car is ahead of hers waiting for a green light. Elizabeth tries to do an emergency stop, but she crashes into Frank's car anyway. He does not suffer any physical injuries, but his car clearly needs some repairs. Elizabeth is in a hurry, so she quickly gets out of the car and gives Frank a card with the insurance details, saying 'I am in a hurry, call my insurance company', and she leaves. Frank thinks that Elizabeth's conduct is inappropriate, but he eventually calls the insurance company, and they pay him all the repairs that were necessary.

In situation (iv), despite the fact that Elizabeth has clearly wronged Frank with her negligent driving, she did not apologise. In a case like this, intuitive morality

\footnotetext{
${ }^{19}$ See for instance Lord Atkin's classic formulation of the tort of negligence in Donoghue $v$ Stevenson: 'The liability for negligence (...) is no doubt based upon a general public sentiment of moral wrongdoing for which the offender must pay'. [1932] AC 562, 580 (House of Lords).
} 
seems to require both an apology and compensation. At least, an apology would be the expected behaviour in the context of modern traffic interactions. But what happens when someone does not apologise? Although compensation is secured by Elizabeth's insurance, her reluctance to sincerely apologise with Frank is problematic. It is true that the law of torts does not generally entitle people to claim for apologies. ${ }^{20}$ In this sense, from a legal perspective in situation (iv) Elizabeth has completely satisfied her duty by repairing - through her insurance - the damage done to Frank's car. But is there something missing here? We can furthermore imagine that situation (iv) happens in New Zealand, where compensation for automobile accidents is secured. As David Enoch points out, on this simple model of New Zealand there is something missing. ${ }^{21}$ According to him, what this scheme misses is that injurers should take responsibility for what they have done, and that this taking-responsibility could be accomplished either with an apology or 'just an explanation coupled with some form of dissociation'.$^{22}$ For Enoch, this is true even in what he calls the 'penumbral agency' cases, in which individuals are not directly responsible for a given result, although their agency is causally involved. ${ }^{23}$

I am not entirely convinced that we should take the argument that far, including cases in which the agent is not at least in a small portion causally responsible and blameworthy for the injury. It is odd indeed that a diligent driver who severely injures a reckless pedestrian does not make any gesture at all to help her victim. Perhaps we would expect the driver to visit her victim at the hospital and to bring her flowers. I share this view, but it also seems to me that we cannot morally demand these gestures from the diligent driver. Maybe he should make those gestures out of courtesy, but they are not morally required in a strong sense. Or it may be that what is missing here is an expression of sympathy, as Smith would call it. ${ }^{24}$ But the reckless pedestrian could not claim that the negligent driver morally failed to visit her at the hospital; after all, it was her own negligence that mainly caused her injuries.

I want to argue that in the case of both apologies and compensation the demands at stake are different. In situation (iv), there is a legitimate moral demand for an apology, which is stronger than a mere expression of sympathy. Both Enoch and Smith agree that there is no single formula for apologies; the circumstances of

\footnotetext{
${ }^{20}$ Offering an apology, however, can be relevant in some legal contexts. See below section IV.

${ }^{21}$ Enoch claims that this imperfect model might be corrected imposing an obligation to apologise. He calls such a system the New Zealand plus apology model. David Enoch, 'Tort Liability and Taking Responsibility' in John Oberdiek (ed), Philosophical Foundations of the Law of Torts (Oxford University Press 2014) 253. It is open to question however how a duty to apologise could be enforced to individuals in such system.

22 ibid 264.

23 ibid 254-8.

${ }^{24}$ Smith (n 4) 34.
} 
each case will determine their content. ${ }^{25}$ Indeed, determining whether Elizabeth's apology or justification was enough is a difficult task. Perhaps we need more information. For instance, it would be interesting to know whether she was really in a hurry or she simply said that to avoid her responsibility. But it seems to me that, unless she really had an emergency or a very important appointment, we would not accept the fact of being in a hurry as a legitimate excuse. After all, we all want to reach our destinations as soon as possible while driving. We could argue therefore, with some degree of certainty, that in situation (iv) Elizabeth has a duty to apologise and also a duty to compensate Frank. What is then the connection between apologies and damages? In this case, both duties seem to run in the same direction. Is it always like that? In other words, is it a happy or unhappy marriage?

\subsection{The happy marriage story: human interaction}

It might be useful to begin establishing what the demands for apologies and damages share. A starting point for this discussion is to claim that human interaction is a necessary condition for both apologies and compensation. ${ }^{26}$ It follows that no demands for compensation or apologies can be raised against nonhuman beings, at least in terms of social morality. For instance, there cannot be a compensatory claim against an animal or a natural object. If my dog eats my dinner, it would be absurd for me to demand something from him in return. I can only try to teach him not to do that again, but I cannot demand an apology or compensation from him. ${ }^{27}$ Similarly, an individual may have a theological duty to repair a sin against God. But such a duty would not concern social morality; it would rather only concern the relationship between the individual and God. Certainly, many aspects of compensatory claims can be studied through the theological notions of atonement and forgiveness. ${ }^{28}$ However, my aim is to answer the questions regarding how to repair actual losses suffered by individuals, leaving aside therefore the discussions that can be raised from a theological point of view.

\footnotetext{
25 'Precisely what it is that living up to the responsibility taken will amount to may depend on the details'. Enoch (n 21) 264. See also above $n 7$.

${ }^{26}$ The idea is particularly powerful for Wright, who thinks that corrective justice can be better categorised as 'interactive justice', a form of justice that regulates all voluntary and involuntary human interactions. Richard W. Wright, 'The Principles of Justice' (2000) 75 Notre Dame Law Review 1859, 1883. See also Finnis' suggestion to use the term 'commutative justice' instead of corrective justice. John Finnis, Natural Law and Natural Rights (2nd ed., Oxford University Press 2011) 177-84.

${ }^{27}$ Interestingly, Smith analyses apologies to animals, claiming that they might have an important meaning for the apologiser. These apologies might indeed be more meaningful than most of the cynical apologies that Smith analyses throughout his book. Smith (n 4) 128.

${ }^{28}$ Two examples of this can be found in Linda Radzik, Making Amends. Atonement in Morality, Law and Politics (Oxford University Press 2009) and Glen Pettigrove, Forgiveness and Love (Oxford University Press 2012).
} 
The human interaction requirement excludes from the scope of both apologies and compensation situations in which no human agency is involved at all. It does not make sense that I apologise for an aerial accident that occurred in Malaysia, because my agency is not in any sense involved in the accident. I might feel sorry for the families of the passengers that were killed, and I can even wish that the accident had never happened. But I have no duty to apologise or compensate the victims. As Smith points out, saying 'I am sorry' to a friend because a close relative has died does not have an apologetic meaning. ${ }^{29}$ It only expresses sympathy for my friend's suffering. This does not mean that my expression of condolences lacks moral value. In fact, depending on how close our friendship is the condolences might be morally required. But what is demanded here is clearly not an apology, which is confirmed by the fact that it would be odd that the recipient of my condolences (my friend) responds to me saying 'I accept your apology'.

As was noted above, even Enoch's idea of taking-responsibility requires some causal intervention of the agent (the 'penumbral agency'), perhaps at least the satisfaction of a but-for test of causation. Similarly, in the case of natural disasters there are no duties to apologise or compensate. If the president of a country says 'I am sorry that the hurricane caused so much damages', he is again expressing sympathy for the victims of the hurricane. However, the scenario would change if the same president says 'I am sorry that we did not take quickly enough the measures that the hurricane required'. In this case, the president is not apologising for the occurrence of a hurricane (which would be meaningless), but he is rather apologising for the government's failure to take the adequate and urgent measures that such a natural disaster required. In this second case thus human interaction is clearly involved, and it is this fact what triggers both duties to apologise and compensate.

\subsection{The tensions of the marriage: compensation with no apologies}

The story of a happy marriage between apologies and compensation needs to be questioned. In this section, I shall stress three conflicting aspects of both reparative mechanisms in which compensation is clearly required, but no apology seems necessary.

\subsubsection{Restitution}

(v) George buys his groceries at the supermarket. He does not realise that the cashier made a mistake giving him the change; he received an extra bill of ten pounds. A few hours later, he finds the ten pounds bill in his wallet, wondering how he could

\footnotetext{
29 'Unless I am confessing to wrongly killing your grandmother and accepting blame for her death, we would not think of a phrase like "I am sorry that your grandmother passed away" as an apology. It offers sympathy rather than contrition'. Smith (n 4) 34 .
} 
have forgotten that he had that bill. So he decides to spend the whole ten pounds buying his favourite chocolates. He eats all of them.

Situation $(v)$ is particularly interesting because compensation is still required, even though no wrong has been committed. There is no wrong here because George never realised that the cashier made a mistake; he never had the intention to deceive him. The supermarket though is entitled to bring an action against George to recover the ten pounds. In contrast with our previous situations, this scenario does not raise a claim to demand for an apology. It would be odd to require George to apologise for what he did. Maybe he should have detected the cashier's mistake; but the same could be argued against the supermarket (the employee should have been more careful). Situation $(v)$ seems to show that committing a wrong is not a necessary condition to have a compensatory claim. However, the supermarket is not entitled here to obtain 'compensation' in the proper (or at least a legal) sense. The appropriate term to be used in this context is 'restitution' rather than compensation, because the legal action would be focused on the unjust gain obtained by George. ${ }^{30}$ This may sound complicated, but if we analyse how the mechanism operates in these cases, we can easily see how the appropriate term is restitution rather than compensation. For instance, if I let my friend use my car for a week, but later he does not want to give it back to me, we would say then that he should give the car back to me. In principle, we would not say that he should provide me with compensation (unless he caused me some harm); the proper remedy is the restitution of my property. Similarly, in situation $(v)$ what is required from George is restitution rather than compensation, because the supermarket's claim will require him to give back the ten pounds he received by mistake.

However, the basic structure of restitution and compensation described above can get more complicated. For instance, in the car example it was already noted that I could have a compensatory claim against my friend if I suffered losses as a consequence of the dispossession of my car. In a similar way, in situation $(v)$ there might be a compensatory claim if we assume that Edward would not have bought the chocolates that he bought had he received the correct change. The question then would be who should bear the loss in such a case. It is clear though that when cases only involve gains and no losses, the operation that takes place is restitution rather than compensation. Restitution cases do not require the existence of a wrong; they rather require someone to have acquired unjust gains at the expense of another. ${ }^{31}$

\footnotetext{
30 "'Restitution" and "compensation" are partners. Compensation is loss-based recovery. Restitution is gain-based recovery'. Peter Birks, Unjust Enrichment (Oxford University Press 2003) 11.

${ }^{31}$ This is particularly pressing for theories of corrective justice that are 'tied to the notion of wrongdoing' - such as Weinrib's - if they seek to justify unjust enrichment under this principle. Prince Saprai, 'Weinrib on Unjust Enrichment' (2011) 24 Canadian Journal of Law \& Jurisprudence 183, 204.
} 
The key issue then is to determine whether gains were acquired unjustly or not. It follows that unjust enrichment claims do not include in general a claim for an apology, since this type of restitution cases are not based on a wrong.

\subsubsection{Strict liability}

(vi) Gladys is a waitress at a restaurant. While she is moving several bottles of Coca Cola to the restaurant's refrigerator, she suffers severe injuries caused by the unexpected explosion of one of the bottles. ${ }^{32}$ Hans is the managing director of the Coca Cola Bottling Company that produced the bottle that exploded in Gladys' hand. He is well aware that the company must provide compensation for the losses suffered by Gladys, although he is convinced that none of the company's employees were negligent. Hans supervises himself every day the production of the bottles, so he knows the production process very well. He refuses to apologise on behalf of the company to Gladys. An insurance company provides compensation to her.

From a legal point of view, in situation (vi) it does not matter whether the bottling company was negligent or not; what matters is that Gladys' injury was in fact caused by a defective product that was manufactured by the bottling company. While the duty to compensate seems to be straightforward in these cases of strict liability, the duty to apologise seems to have a different story. Is it possible for Gladys to morally demand an official apology on behalf of the bottling company? Certainly, companies usually apologise for incidents like this, by saying 'We are sorry, but we took all the necessary precautions'. As was noted above, such an apology would be a mere expression of sympathy according to Smith's framework of apologies, because the company expresses regret for the accident, but is at the same time justifying or excusing its behaviour. But it might be the case that only an expression of sympathy is what the circumstances of the situation require here.

Certainly, the fact that the insurance company will be paying for the damages to Gladys is an additional difficulty. Should not we demand that the duty to pay damages be necessarily fulfilled by the injurer herself? Does it make a difference if the bottling company pays by itself (at least part of) the damages to Gladys? Perhaps the fact that the Coca Cola Company directly compensates Gladys is a meaningful expressive gesture for her, a meaning that cannot be reached when the insurance company exclusively provides the damages. ${ }^{33}$

\subsubsection{Compensation through Insurance}

32 Escola v Coca Cola Bottling 150 P2d 436 (Supreme Court of California 1944).

${ }^{33}$ The same point is raised in Gardner (n 5) 110. 
Another source of conflict between apologies and compensation mechanisms may arise as a consequence of the effects of insurance. The question here is whether we should allow injurers to fulfil their duties of justice through third parties. While most corrective justice theorists are not troubled with the fact that insurance companies and not injurers themselves compensate their victims, ${ }^{34}$ the duty to apologise seems to operate differently. If a parent apologises for her children's conduct, the apology is acceptable only because the child is unable to understand that an apology is required for what she did. It might also be the case that the parent is apologising for her own conduct, failing to prevent that her child commits the wrong. But an apology from a third party in general is not appropriate. Is this problematic for the operation of compensatory mechanisms?

It was already suggested that the solution might be to establish a 'New Zealand plus apology' system, in which compensation is secured and injurers are required to apologise to their victims. ${ }^{35}$ Insurance companies however may disagree with such a system. They usually advise their policyholders not to apologise, because such gesture could imply an assumption of legal responsibility, even when the injurer is not legally liable. ${ }^{36}$ Let us go back to situation (iv). Imagine now that Elizabeth wants to apologise for her negligent driving, but she remembers that her insurance company instructed her not to apologise if she gets involved in an accident. Can we still demand her to apologise?

\section{RESTORATIVE JUSTICE AND SYMBOLIC REPARATIONS}

In the previous sections, it was noted that apologies require the concurrence of some kind of human interaction and a wrong. But why are apologies morally required? Are there any normative aspects of apologies, or are they just a common practice of courtesy like giving thanks to the cashier at a cafeteria? This seems to be matter of degree. On one hand, serious wrongs require serious apologies, just like serious gifts require serious acts of gratitude. On the other hand, less severe wrongs may only require a quick apology, or even a small gesture. My aim is to argue that both apologies and compensation mechanisms are morally required when wrongs occur. I will claim that these moral requirements are stronger than just mere etiquette rules, because they are duties of restorative justice. This section will deal with apologies and their symbolic role to provide reparations for wrongs by restoring moral relationships.

Let me begin the analysis by asking what the aim of apologies is. Following Walker and Marshall, among others, I argue that apologies are expressive speech

\footnotetext{
${ }^{34}$ For instance, for Coleman, the role of the insurance mechanism is restricted to allow individuals to fulfil their duties of justice through a third party. Jules L Coleman, Risks and Wrongs (Cambridge University Press 1992) 206.

35 Enoch (n 21) 253.

${ }^{36}$ For a discussion, see Prue Vines, 'Tortious Liability in Negligence and Insurance', in Kit Barker et al. (eds.), Private Law in the 21 ${ }^{\text {st }}$ Century (Hart Publishing 2017) 292-295.
} 
acts that seek to regain stability in our moral relations. ${ }^{37}$ As Gardner rightly puts it, an apology is 'an expression of agent-regret' that can 'be used derivatively as a device for repairing damaged relationships' ${ }^{38}$ When wrongs occur, moral relations are usually threatened by resentment, which is the 'reactive attitude' we have when someone has wronged us. ${ }^{39}$ Restorative justice demands that the injurer make amends to her victim to restore the moral relationship that has been damaged. Resentment is a negative feeling towards the injurer, but it is not a morally wrong emotion. It is rather the adequate response to wrongs. ${ }^{40}$ Indeed, as Murphy points out, in many cases lack of resentment can be a symptom of lack of self-respect. ${ }^{41}$

Apologies under the framework of restorative justice seek to restore an adequate moral relationship, and therefore seem to suggest that it only deals with interactions among people that had a previous moral relationship, such as friendship, family, work colleagues, and so on. ${ }^{42}$ However, it is not necessary to know previously the person that has been injured to have a duty of restorative justice. It is true that usually it is more difficult to forgive the persons who we love most when they have wronged us. Certainly, when there is a pre-existent relationship between the injurer and the victim, it makes more sense to seek the restitution of a previous moral relationship. But what happens in the case of people who do not previously know each other? In these cases there is still a moral relationship to be restored, which is the relationship among anonymous citizens. Wrongs can damage relationships even between strangers, because wrongs usually violate general rules of conduct that precisely describe the duties that every citizen should comply with. Marshall correctly points out that apologies restore mutual respect. She is also right when she claims that the context in which a wrong occurs

\footnotetext{
${ }^{37}$ Sandra Marshall, 'Noncompensatable Wrongs, or Having to Say You're Sorry' in Matthew Kramer, Rights, Wrongs and Responsibilities (Palgrave 2001); Margaret U. Walker, Moral Repair (Cambridge University Press 2006) 6.

${ }^{38}$ Gardner (n 5) 149.

39 Peter F. Strawson, 'Freedom and Resentment' in his Freedom and Resentment and Other Essays (Routledge 2008) 1-28.

40 'The moral emotions of resentment and indignation, as distinguished from simple anger, are responses to wrongs. Gerald F. Gaus, 'Does Compensation Restore Equality?' in Rodney C. Roberts (ed.), Injustice and Rectification (Peter Lang 2002) 101.

${ }^{41}$ Jeffrie G. Murphy, 'Forgiveness and Resentment' (1982) 7 Midwest Studies in Philosophy 503, 505.

42 Both Encarnacion and Hershovitz seem to endorse this view, arguing that the ideal of reconciliation works better in the case of interactions among people who know each other previously. Erik Encarnacion, 'Corrective Justice as Making Amends' (2014) 62 Buffalo Law Review 451, 503; Scott Hershovitz, 'Patching Things Up', Jotwell (May 13, 2014) (reviewing Linda Radzik, 'Tort Processes and Relational Repair' in John Oberdiek [ed.], Philosophical Foundations of the Law of Torts [OUP 2014]), http://torts.jotwell.com/patching-things-up/.
} 
determines the content of the apology. ${ }^{43}$ For instance, if I wronged a friend, my apology will be different than if I wrong a colleague at work or a complete stranger.

It seems to me though that apologies have a normative aspect involved that is not necessarily covered by Marshall's idea of mutual respect. Apologies usually do restore a condition of mutual respect; if I make an embarrassing joke about a colleague at work, I must indeed apologise to re-establish our mutual respect as colleagues. However, the point I want to stress here is that my apology also restores my respect to the rules of conduct I have infringed when I committed the wrong. In this case, the rules of conduct among colleagues have been clearly infringed. Usually these rules are not written (unless the company has a sort of manual for employees' good behaviour), but every employee knows them and expects others to comply with them. In this sense, nobody needs to tell me that making an embarrassing joke about a colleague is not an acceptable behaviour in the workplace. It is true that my apology restores mutual respect, but it also restores my respect to the rules of conduct that have been infringed. ${ }^{44}$

It is true that resentment is usually triggered by demeaning acts that are disrespectful to the victim's 'individual's worth'. ${ }^{45}$ In this sense, the normative aspect of apologies might be blurred in the case of serious wrongs, where the restitution of mutual respect is more visible. But in less serious wrongs, the element of mutual respect tends to disappear, while the respect to the rules of conduct involved becomes more relevant. ${ }^{46}$ For instance, in our situation (i), it seems to me that it would be slightly exaggerated to claim that Barbara must apologise to Alfred because she did not treat him with the respect or dignity that he deserves. In this sense, the normative approach of apologies explains the problem more accurately:

\footnotetext{
${ }^{43}$ Marshall (n 37) 220. And as Encarnacion points out, the nature of the wrong is also important: 'making amends might require a broad range of appropriate responses, which are sensitive to, among other things, the nature of the wrong'. Encarnacion (n 42) 496.

${ }^{44}$ I am fully aware that according to some moral frameworks, such as Kant's or Waldron's notion of human dignity, morality requires equal respect among human beings. Jeremy Waldron, 'Lecture 1: Dignity and Rank' in Meir Dan-Cohen (ed.), Dignity, Rank, and Rights (Oxford University Press 2012) 30-6. But my normative framework for apologies is compatible with these theories, because if it indeed were true that we generally share (or should share) a notion of human dignity as a high-ranking status that should be assigned to everyone, then this would be the normative framework that apologies restore. However, my approach is broader, because it allows including situations in which high values, such as human dignity, are not necessarily at stake.

${ }^{45}$ Jean Hampton, 'Forgiveness, Resentment and Hatred' in Jeffrie G. Murphy and Jean Hampton (eds.), Forgiveness and Mercy (Cambridge University Press 1988) 53.

${ }^{46}$ Smith also emphasises this normative aspect of apologies, requiring injurers to endorse the moral principles that underlie in the harm caused. Smith (n 4) 60-3. However, Smith's theoretical framework is narrower than mine, because he also argues that injurers should recognise their victims as 'moral interlocutors', which involves the abandonment of 'viewing the victim as a mere means subordinated to the offender's ends'. ibid 65. The reference to Kant's framework of equal respect or dignity is clear.
} 
there are rules of behaviour applicable to people buying at the groceries fair market (let us call them 'rules for groceries markets'), according to which consumers grab all the vegetables and fruits they want and then wait on the line to pay. Barbara's apology may reinstate mutual respect among strangers at the groceries fair market; but with more precision, it restores the respect to the rules for groceries markets. By apologising, Barbara is expressing regret for what she did, showing that she understands that she should not have violated the rules for groceries markets, and communicating an egalitarian message: no one is beyond the rules. ${ }^{47}$

The normative framework of apologies therefore allows explaining more accurately how they operate in the case of less serious wrongs. It also explains why the context in which the wrong occurs is important, because only looking at the context it is possible to understand which rules of behaviour are involved. Furthermore, the framework also explains why it could be argued that apologies restore moral equality. ${ }^{48}$ In this sense, the rules of behaviour that have been infringed by the wrong are the baseline for the equality that needs to be restored with the apology. Moral equality then is restored only when respect to the infringed rules of conduct is reinstated through a proper apology. Finally, it is important to stress that there are other mechanisms besides apologies that can also restore moral relationships.

\section{CORRECTIVE APOLOGIES AND RESTORATIVE DAMAGES}

So far, it has been argued above that the framework of apologies is restorative justice, where the goal is to restore moral relationships. However, in some cases it is possible to claim that apologies perform a corrective justice function. In this sense, the law of torts has a specific example of corrective apologies, namely: the role of apologies in the tort of defamation in English law. In this tort, the defendant is able to mitigate the damages to be paid if an apology has been made or offered. ${ }^{49}$ I argue that in the context of the tort of defamation, apologies perform a double function. There is a restorative justice function, which seeks to restore the moral relationship between the parties. According to resentment-based theories, the injurer has demeaned the victim of the defamation, and therefore an apology would seek to reconcile the victim with the tortfeasor. On the other hand, under a normative framework of restorative justice, an apology would seek to restore the equal respect to the rules according to which no one should publish defamatory statements. Accordingly, if the injurer says 'I am sorry for publishing this false

\footnotetext{
${ }^{47}$ Goldberg and Zipursky have also suggested that tort damages communicate this egalitarian message. John C.P. Goldberg and Benjamin C. Zipursky, 'Torts as Wrongs' (2010) 88 Texas Law Review 917, 982.

48 This argument can be found in Gaus (n 40).

${ }^{49}$ Defamation Act 1996 s 3(5). This is also legislated in Australia and Canada. See Robyn Carroll and Jeffrey Berryman, 'Making Amends by Apologising for Defamatory Publications', in Kit Barker et al. (eds.), Private Law in the 21 ${ }^{\text {st }}$ Century (Hart Publishing 2017) 485-487.
} 
statement', what she really means is 'I am sorry for infringing the rules of defamation'.

Whether one accepts a resentment-based account of restorative justice or a normative one, it is clear that apologies perform a restorative justice function. In this case however apologies also perform a corrective justice function. By allowing the injurer to mitigate the damages that she is required to pay, the apology is in fact replacing some of the amount that corrective justice requires the injurer to pay. In this context, the apology is not only restoring the moral relationship, but it is also compensating the losses suffered by the victim as a consequence of the wrong (the act of defamation). Hence, there is conceptual space for corrective apologies, and the law of torts provides a specific example of this possibility.

Many tort scholars have argued that the law of torts encompasses the principle of corrective justice, regardless of their disagreement about the content of that principle. ${ }^{50}$ But the question that needs to be explored here is whether it is possible to argue that it also endorses a notion of restorative justice.

Situation (vi) is clearly a case in which compensation is not performing the symbolic function of restorative justice. There are though other cases in which compensation does perform this function:

(vii) Neil, a professor of an important university, promises his children to take them to the beach the weekend to follow. But he is unable to keep his promise, because he forgets that he needs to mark some papers for next week. Neil feels so bad for this that he takes his children to Disneyland the weekend after. ${ }^{51}$

In MacCormick's original well-known example, the professor is unable to keep his promise because he is required to help a student with an apparently suicidal depression. This might be a case in which 'penumbral agency' is involved: Neil did not commit a wrong when he broke his promise, because he had the obligation to attend the student's urgent situation. ${ }^{52}$ But in situation (vii) I have cleared out the entire penumbra doubts on agency. It is Neil's negligence that makes him liable here. The question that needs to be answered then is the following: does Neil satisfy his duty of justice by taking his children to Disneyland? To determine which specific reparative measures are required will depend on the circumstances of the

${ }^{50}$ E.g. Coleman (n 34); Allan Beever, Rediscovering the Law of Negligence (Hart Publishing 2007); Ernest J Weinrib, The Idea of Private Law (revised edn., OUP 2012).

${ }^{51}$ This is a slightly modified version of MacCormick's famous example: D.N. MacCormick, 'The Obligation of Reparation' (1977) 78 Proceedings of the Aristotelian Society 175.

${ }_{52}$ MacCormick's example is, in my view, a particularly interesting example for Enoch's theory, because it emphasises his parallel between taking responsibility for some 'penumbral agency' case and making a promise. Enoch (n 21) 259. See also Gardner's example of him not being able to give a lecture for the cancellation of a flight. Gardner (n 5) 98-101. 
case. But it seems to me that what is interesting in situation (vii) is that it shows that corrective justice may impose the duty to symbolically repair the harm done. The trip to Disneyland is not a mere payment of damages (though Neil will obviously have to pay for the trip), but it is an expression of Neil's regret for failing to keep his promise. It is possible therefore for corrective justice to have a symbolic meaning that potentially restores moral relationships.

There is however always a worry with damages: in many cases, they could be insulting and demeaning. Radzik warns us that the mere payment of damages may sometimes deteriorate moral relationships:

$[P]$ ayments are objectionable when they are represented as a form of restitution, which suggests that the value damaged and the value offered in response are fungible and that the latter could be exchanged for the former without the loss. To suggest that money is a suitable restitution for pain and suffering is an insult to the victim. ${ }^{53}$

But she also argues that it is possible for material redress to assume a symbolic function. To perform this function, she claims that 'reparation payments must either be accompanied by other, perhaps verbal, forms of communication or else take place within a social institution or tradition of reparation payments that constructs such an acceptable meaning.${ }^{54}$ Is it possible then to argue that the law of torts provides the institutional background that Radzik requires for compensation to perform a symbolic function? It seems to me that the basic structure of tort law based on the interaction between injurers and victims allows performing this restorative function in most of the cases. My aim is not to claim that all existing tort systems successfully perform this symbolic function. Many aspects of tort litigation, for instance, do not help to restore moral relationships; they sometimes increase disagreements and resentment between the parties. However, the claim according to which in some cases tort law is able to perform a symbolic function opens the debate to many questions that have not been discussed by legal scholars, who have focused the debate mainly on the notion of corrective justice. To claim that it is possible to understand the law of torts in terms of a symbolic practice that seeks to restore moral relationships allows questioning which of its features contribute to this aim, and which of them do not. It provides thus a moral criterion to evaluate existent tort systems. But more importantly, it also shows that

\footnotetext{
53 Radzik (n 28) 98.

54 ibid. Walker also suggests that it is possible for the classical account of corrective justice to perform this function; however, she argues that this will only be possible if corrective justice consolidates 'a more varied and complex process of historical accounting, acknowledgment, cultivating trust and making amends for which restorative justice provides the rationale'. Margaret U. Walker, 'Restorative Justice and Reparations' (2006) 37 Journal of Social Philosophy 377, 391-2.
} 
tort systems could encompass the demands of both corrective and restorative justice. It follows that if someone wants to discuss substantial reform of tort law or its abandonment, this symbolic function of tort law should also be considered because, to some extent, tort law is like apologies.

\section{REFERENCES}

BIRKS, Peter. Unjust Enrichment, Oxford University Press, 2003.

COLEMAN, Jules L. Risks and Wrongs, Cambridge University Press, 1992.

ENOCH, David. Tort Liability and Taking Responsibility in John Oberdiek (ed), Philosophical Foundations of the Law of Torts, Oxford University Press, 2014.

FINNIS, J. Natural Law and Natural Rights, 2nd ed., Oxford University Press 2011.

GARDNER, J. From Personal Life to Private Law, Oxford University Press, 2018.

GILL, Kathleen. The Moral Functions of an Apology, 31 The Philosophical Forum, 2000.

HONORÉ, Tony. Responsibility and Luck. The Moral Basis of Strict Liability in his Responsibility and Fault, Hart Publishing, 1999.

KORT, Louis F. What is an Apology? in Rodney C. Roberts (ed), Injustice and Rectification, Peter Lang, 2002.

PETTIGROVE, Glen. Forgiveness and Love, Oxford University Press, 2012.

RADZIK, Linda. Making Amends. Atonement in Morality, Law and Politics, Oxford University Press, 2009.

SEARLE, J. Speech Acts: An Essay in the Philosophy of Language. Cambridge University Press, 1969.

SMITH, N. I Was Wrong: The Meaning of Apologies, Cambridge University Press, 2008.

SMITH, N. The Categorical Apology, 36 Journal of Social Philosophy, 2005. 
STRAWSON, Peter F. Freedom and Resentment in his Freedom and Resentment and Other Essays, Routledge, 2008.

VINES, Prue. Tortious Liability in Negligence and Insurance in Kit Barker et al. (eds.), Private Law in the $\mathbf{2 1}^{\text {st }}$ Century, Hart Publishing, 2017.

WRIGHT, Richard W. The Principles of Justice, 75 Notre Dame Law Review, 2000 . 